\title{
GEOCHRONOLOGY OF GRANITOIDS FROM PSUNJ AND PAPUK MTS., CROATIA
}

\author{
MARIJA HORVAT ${ }^{1}$, URS KLÖTZLI ${ }^{2}$, DOMAGOJ JAMIČIĆ ${ }^{3}$, GYÖRGY BUDA ${ }^{4}$, \\ EVA KLÖTZLI ${ }^{2}$ and CHRISTOPH HAUZENBERGER \\ ${ }^{I}$ Croatian Geological Survey, Department of Geology, Sachsova 2, 10000 Zagreb, Croatia \\ ${ }^{2}$ University of Vienna, Department of Lithospheric Research, Althanstraße 14, A-1090 Vienna, Austria \\ ${ }^{3}$ Svetojanska 21, 10000 Zagreb, Croatia \\ ${ }^{4}$ Eötvös Lóránd University, Institute of Geology, Department of Mineralogy, Pázmány Péter sétány 1/c, H-1117 Budapest, Hungary \\ ${ }^{5}$ Karl-Franzens-University, Department of Earth Sciences, Universitätsplatz 2, 8010 Graz, Austria
}

Received 27 August 2017

Accepted 12 September 2018

\begin{abstract}
Detailed cathodoluminescence (CL) and back scattered electron (BSE) imaging of zircon crystals, coupled with in-situ U-Pb zircon dating by Laser Ablation Multi-Collector Inductively Coupled Plasma Mass Spectrometry (LA-MC-ICP-MS) were used to develop new insights into the evolution of a monzogranite from Omanovac Quarry (Psunj Mt.), and of monzogranites from Šandrovac Quarry and Kišeljevac Creek (Papuk Mt.), both located in the Slavonian Mountains (Croatia).

$\mathrm{U}-\mathrm{Pb}$ isotopic data yielded a concordia age of $380 \pm 4 \mathrm{Ma}$ for the monzogranite from Omanovac Quarry, and $382 \pm 2 \mathrm{Ma}$ and $383 \pm 5 \mathrm{Ma}$ for monzogranites from Šandrovac Quarry and Kišeljevac Creek. The results suggest Late Devonian magmatic activity.
\end{abstract}

Keywords: zircon geochronology, monzogranite, Late Devonian, Psunj Mt., Papuk Mt., Croatia.

\section{INTRODUCTION}

The Slavonian Mountains in Croatia, comprising the Psunj, Papuk and Krndija mountain ranges (Fig. 1), represent a complex geological structure created by numerous tectonic events throughout the geological history of the Tisia Megaterrane/Tisza Mega-Unit basement in the Circum Pannonian Region (CPR, Ebner et al., 2008) or Alpine-Carpathian-Dinaridic orogenic system (ACD, Schmid et al., 2008). The Tisia Megaterrane/Tisza MegaUnit is commonly regarded as a lithosphere fragment which broke off the southern margin of Variscan Europe during the Jurassic. After complicated drifting and rotational processes, it became emplaced in its present-day

Corresponding author: M. Horvat e-mail: mhorvat@hgi-cgs.hr setting in the Pannonian Basin during the Early Miocene (Balla, 1986; Csontos et al., 1992; Szederkényi, 1996; Horváth, 1993; Haas and Péró, 2004).

The pre-Alpine terranes of Tisia accompanied Slavonian inselbergs in Slavonia-Dravia Terrane (Slavonia Drava Unit), according to Kovács et al. (2000), or the Bihor nappe system, according to Schmid et al. (2008; 2016) (Villány-Bihor Zone or unit of Bleahu et al., 1996 and Haas and Péró, 2004; Papuk-Codru Zone of Haas, 2015) (Fig. 1A).

The most detailed reports on the geology of the Psunj and Papuk Mts. are geological 1/100,000 scale maps, Daruvar (Jamičić, 1989) and Orahovica (Jamičić and Brkić, 1987) sheets, and corresponding explanatory notes (Jamičić et al., 1987; 1989).

Jamičić (1988; 2001), based on petrographical and structural data, distinguishes three series of basement rocks: a) Psunj-Krndija Complex, b) Papuk Complex and c) Radlovac Complex (Fig. 1C). Their geological evolu- 


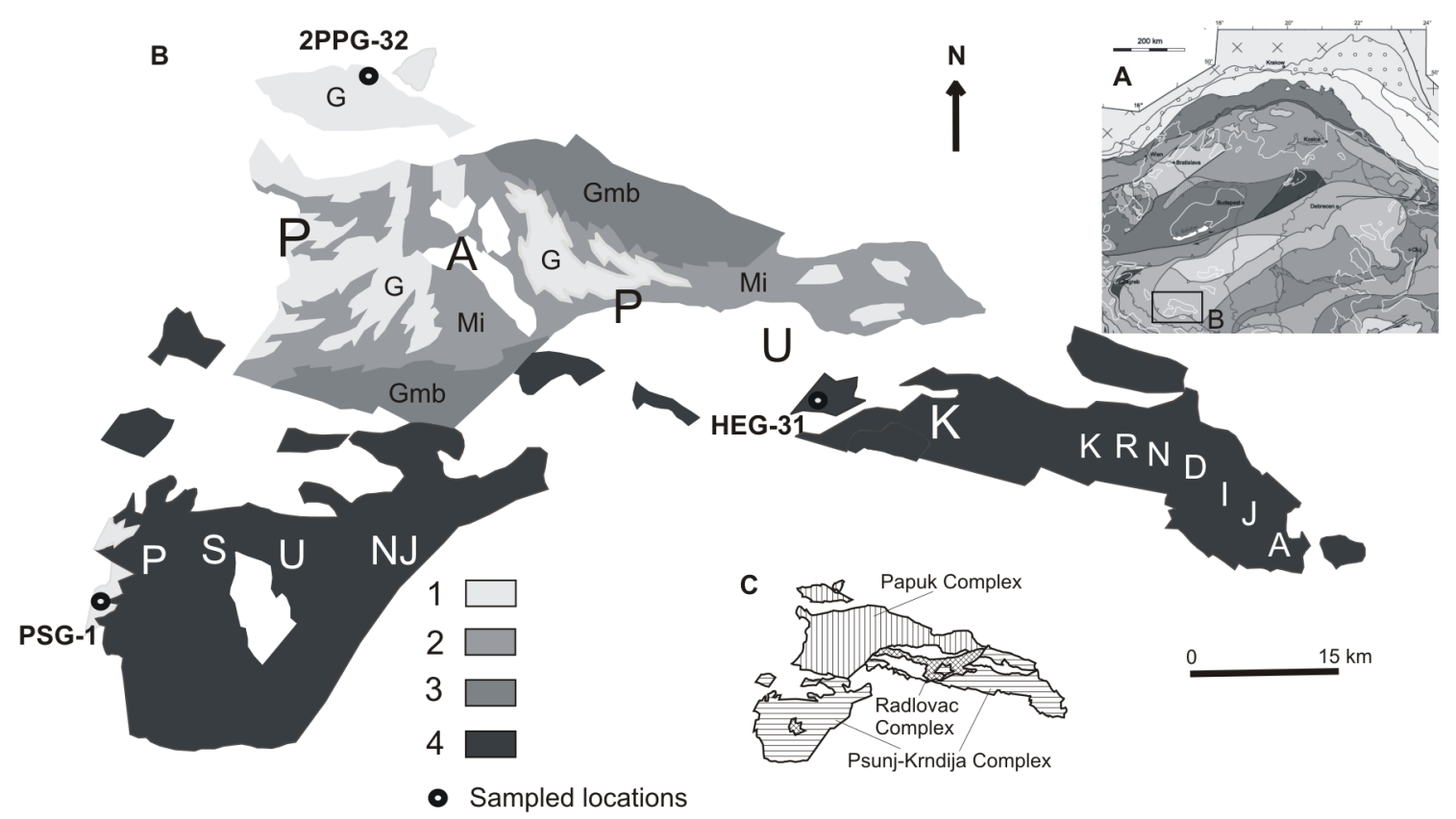

Fig. 1. A - tectonic map with major tectonic units of the Alps, Carpathians and Dinarides (Schmid et al., 2016), with the position of the Slavonian Mts. (Croatia) marked by a black rectangle (B). B - The geology of the crystalline basement rocks of the Slavonian Mts. A simplified geological outline of the Slavonian Mts. (Psunj, Papuk and Krnidja) (according to Jamičić, 2001) with sampled locations: PSG-1 Omanovac Quarry (Psunj Mt.), 2PPG-32 Šandrovac Quarry (NW Papuk Mt.) and HEG-31 Kišeljevac Creek (S slope of Papuk Mt.). Legend: 1 - Graniotoids (G), 2 - Migmatites (Mi), 3 - Biotite-muscovite gneiss (Gmb), 4 - garnet-staurolite gneiss, kyanite gneiss, sillimanite gneiss, amphibolite, metagabbro, amphibole-schist, chlorite-sericite schist and flaser granitoids, and other different types of granitoids with marble. C - Schematic drawing of three series of basement rocks: the Psunj-Krndija, Papuk and Radlovac Complexes.

tion is interpreted as representing three phases of sedimentation and metamorphism, from the Precambrian (questionable) to the Upper Permian: a) the Psunj-Krndija Complex is assumed to have metamorphosed progressively during the Baikalian orogeny and retrogradely during the Caledonian orogeny (b) the Papuk Complex is marked by migmatisation, granite intrusions and metamorphism in the pre-Variscian time and c) the Radlovac Complex is characterised by low-grade metamorphic overprinting during the Variscan orogeny.

Pamić and Lanphere (1991), and Pamić et al. (1988a; 1996) distinguish five main groups of crystalline rocks of the Pannonian Basin in the Slavonian Mountains and the surrounding basement: 1 . the weakly metamorphosed (semimetamorphic) complex; 2 . the progressively metamorphosed complex; 3. migmatites; 4. S-type granites and 5. I-type granites. They concluded that all of these were produced during the Hercynian orogeny.

The aim of this paper is to solve the basic geochronological question about the igneous age of monzogranites from Psunj and Papuk Mts. (Slavonia, Croatia). For this purpose, in-situ laser ablation U-Pb zircon dating was applied. The paper shows that the investigated granite intrusions had occurred earlier (in Late Devonian) than previous radiometric studies have reported.

\section{GEOLOGICAL SETTING}

The Basic Geological Map $(1 / 100,000)$ of the Slavonian Mountains (Psunj, Papuk, and Krndija), Daruvar (Jamičić, 1989) and Orahovica (Jamičić and Brkić, 1987) sheets cover the area between the Sava and Drava Rivers, bordered by $45^{\circ} 20^{\prime}$ and $45^{\circ} 40^{\prime}$ north latitudes, and $17^{\circ} 00^{\prime}$ and $18^{\circ} 00^{\prime}$ east longitudes. A schematic geological map, simplified according to the geological map of Jamičić (2001) and including sampled locations, is presented in Fig. 1B. The oldest exposed rocks from Psunj Mt. are the metamorphic rocks: garnet-staurolite gneiss, kyanite gneiss, sillimanite gneiss, amphibolite, metagabbro, amphibole schist, chlorite-sericite schist, graphitebearing schist and flaser granitoids (granodiorite and plagiogranite types) (Jamičić et al., 1987; 1989). The same rocks also constituted the southern slope of Papuk Mt. and most of Krndija Mt. (Fig. 1B). The granitoids occur in the W part of Psunj Mt. (Marci, 1965; 1971; 1973), the S slope of Papuk and Krndija Mts. (Jamičić, 1983; Jamičić et al., 1987; Pamić, 1988). Pamić et al. (1996) classified it as I-type. In the Kišeljevac Creek valley (the $\mathrm{S}$ slope of Papuk Mt.), a significant contact aureole could be found around granitoid body, with marble formation (Jamičić and Brkić, 1987). I-type granitoids 
are associated with intermediate and basic igneous rocks, as well as with ultramafic rocks (Pamić et al., 1984a; 1984b). Horvat and Buda (2004) described three different granitoid types associated with the Psunj-Krndija Complex (Omanovac Quarry amphibole monzogranite, Kišeljevac Creek biotite monzogranite and Bistra Creek quartz diorite) showing mixed I/S-type character. According to the proposed petrogenetic interpretation of granitoid rock series using multi cationic parameters R1 and R2 (de la Roche et al., 1980), the mentioned rock types plot in the different tectonic position fields: pre-plate collision and syncollision (Horvat and Buda, 2004).

Recent studies by Balen et al. (2006; 2013), Horváth et al. (2010) and Balen et al. (2015) have provided mainly monazite dating results for medium-grade metamorphic rocks (micaschist, gneiss and amphibolite) from the Psunj-Krndija Complex. These data have emphasised the occurrence of Cambrian-Ordovician ages (528 7 and $465 \pm 7 \mathrm{Ma}$; Balen et al., 2015), an Ordovician-Silurian metamorphic event at peak assemblage monazite growth reaching amphibolite facies conditions of $\mathrm{ca} .600-650^{\circ} \mathrm{C}$ and 8-11 kbar $(444 \pm 19$ and $428 \pm 25 \mathrm{Ma}$; Balen et al., 2006) and Variscan ages (monazite Th-U-Pb age data) for the Krndija Mt. mica schists (356 $\pm 23 \mathrm{Ma}$; Horváth et al., 2010).

In the central part of Psunj Mt. and in the connection zone between Papuk and Krndija Mts., Late Devonian coarse-grained sandstones and graphite-bearing slates (Fig. 1C) are continuously covered by Carboniferous and Lower Permian metagraywackes and slates (Jamičić et al., 1987; 1989). Black slates are Westphalian (B and C) in age according to the fossil flora (Brkić et al., 1974). A few small diabase intrusions are connected to this zone (Jamičić, 1983; 1988; Pamić and Jamičić 1986). Further, the permotriassic sediments also could be found in the Papuk-Krndija connection zone. They are divided into two groups: ${ }^{1} \mathrm{PT}$ violet conglomerates (pebbles are phyllites, slates and/or metagraywackes) and ${ }^{2} \mathrm{PT}$ green- to grayish green-colour quartz sandstones and arkoses (Jamičić et al., 1987). The provenance and depositional history of very low- to low-grade metasedimentary rocks of the Radlovac Complex was investigated by Biševac et al. (2010; 2013). K-Ar ages ( 100-80 Ma) measured on illite-white $\mathrm{K}$-mica rich $<2 \mu \mathrm{m}$ grain-size fractions pointed to Late Cretaceous very low- to low-grade regional metamorphism, presumably related to the main nappe-forming compressional events in the Pannonian Basin and the Carpathians (Biševac et al., 2010). The provenance study of the Radlovac Complex metasedimentary rocks based on $\mathrm{Th}-\mathrm{U}-\mathrm{Pb}$ monazite chemical age dating, heavy mineral assemblage and whole-rock geochemistry led to the conclusion that the metasedimentary rocks of the Radlovac Complex represent the detritus of the local Variscan crust, and that the major source was felsic, igneous rocks, while Papuk Complex rocks were the dominant source material (Biševac et al., 2013). This is in good agreement with the model proposed by Jamičić (1988).

The central parts, eastern and northern slopes of Papuk Mt. comprise of biotite gneisses and muscovitebiotite gneisses, micaschists, homogeneous and heterogeneous migmatites, granitoids, pegmatites and aplites (Jamičić et al., 1987; 1989). Granitoids of the NW part of the Mt. Papuk have a mineral composition corresponding to granite, granodiorite, quartzdiorite and leucocratic tonalite varieties, and can be found as distinct large bodies, lenses or veins in migmatites (Vragović, 1965). The succession of metamorphic zones imperceptibly grading into each other (Papuk Mt.) could be followed continuously as a progressive metamorphic sequence, with following metamorphic index minerals: chlorite $\rightarrow$ biotite $\rightarrow$ garnet $\rightarrow$ staurolite $\rightarrow$ sillimanite (Raffaelli, 1964). In addition, andalusite was found in these schists by Pamić et al. (1988b). Less abundant micaschists can be found at the northern slope of Papuk Mt. Gneisses and micaschists continuously grade to migmatites in all locations (Jamičić et al., 1989; Pamić and Lanphere, 1991). Pegmatites and aplites occur as veins, irregular nests in the migmatitic zone, in the zone of muscovite-biotite gneiss and in granitoid bodies (Horvat et al., 2002; Kovács Kis et al., 2004 and references therein). Pegmatites contain large pink, pinkish gray or gray feldspars as megacrysts (Jamičić et al., 1989). Amphibolites and amphibole schists are intercalated in the migmatites and gneisses. Based on microscopic descriptions, major element data, and oxygen isotope geochemistry, Pamić and Marci (1990) and Pamić et al. (2002) summarised the petrography and geochemistry of the amphibolites of Mts. Psunj and Papuk, documenting that all of them represent orthoamphibolites. Serpentinites featuring relicts of peridotite were found only in one Papuk Mt. location and in the central part of Psunj Mt. (Jamičić and Brkić, 1987; Jamičić, 1989). Granitoid plutons within the migmatitic complex are composed mainly of S-type granites and subordinate intermediate rocks (Pamić and Lanphere, 1991). Horvat and Buda (2004) published syncollision and postcollision magmatism affinity for seven samples from the Papuk Complex, monzogranite and granodiorite types, using multi cationic parameters R1 and R2 (de la Roche et al., 1980), classifying majority of them as S-type and $\mathrm{I} / \mathrm{S}$-type as well.

The process of phyllonitisation is detected in the whole area and it is one of the features of retrograde metamorphism.

\section{MATERIAL AND METHODS}

The geochemistry of amphibole monzogranite from Psunj Mt. and of different granitoid types of Papuk Mt. were originally presented by Horvat and Buda (2004). Of these samples, sample from Psunj Mt. (Omanovac Quarry, the PSG-1 sample) and two from Papuk Mt. 
(Šandrovac Quarry, the 2PPG-32 sample and Kišeljevac Creek, the HEG-31 sample) were selected for further geochronological investigations (Fig. 1B).

Mineral separation was carried out at Eötvös Loránd University (Budapest, Hungary) using standard techniques (crushing, hydro-fracturing, washing, heavy liquids and magnetic separation). 80 (PSG-1), 74 (2PPG-32) and 105 (HEG-31) zircon crystals, were hand-picked and mounted in 1-inch epoxy-resin mounts according to their translucency and grain size at the University of Vienna (Austria). Zircon grains were imaged by panchromatic cathodoluminescence on a VEGA/TESCAN SEM $(15 \mathrm{kV}$ and $8 \mathrm{nA}$ ) at the Geological Survey of Austria (GBA Vienna, Austria).

The LA-ICP-MS analytical work was performed at the joint ICP-MS laboratory of the Department of Earth Sciences, Karl-Franzens-Universität Graz and the Institute of Applied Geosciences, Graz Technical University. Analytical procedures were identical to the methodology outlined in Klötzli et al. (2009). Zircon U-Th-Pb isotopic and elemental ratios were determined using a $193 \mathrm{~nm}$ ArF excimer laser (NewWave) coupled to a multi-collector ICP-MS (Nu Instruments II). Ablation using He as carrier gas was raster- and spot-wise according to the CL zonation pattern of the zircons. Line widths for rastering were $10-15 \mu \mathrm{m}$ with a rastering speed of $10 \mu \mathrm{m} / \mathrm{sec}$. Energy densities were $c a .5 \mathrm{~J} / \mathrm{cm}^{2}$ with a repetition rate of $10 \mathrm{~Hz}$. The He carrier gas was mixed with the Ar carrier gas flow prior to the ICP plasma torch. Ablation duration was 30 to $70 \mathrm{sec}$ with a $30 \mathrm{sec}$ gas and $\mathrm{Hg}$ blank measurement preceding ablation. Ablation count rates were corrected accordingly offline. Remaining counts on mass 204 were interpreted as representing ${ }^{204} \mathrm{~Pb}$. Static mass spectrometer analysis was as follows: ${ }^{238} \mathrm{U}$ and ${ }^{232} \mathrm{Th}$ were measured by Faraday ion-counter, ${ }^{208} \mathrm{~Pb},{ }^{207} \mathrm{~Pb},{ }^{206} \mathrm{~Pb}, 204(\mathrm{~Pb}+\mathrm{Hg})$, and ${ }^{202} \mathrm{Hg}$ in ion counter detectors, respectively. An integration time of $1 \mathrm{sec}$ was used for all measurements. The ion counter - Faraday and inter-ion counter gain factors were determined before the analytical session using the Plešovice reference zircon (Sláma et al., 2008). The sensitivity for ${ }^{206} \mathrm{~Pb}$ on the Plešovice reference zircon was $c$. $0.092 \mathrm{mV} / \mathrm{ppm} \mathrm{Pb}$. For ${ }^{238} \mathrm{U}$ the corresponding value was c. $0.147 \mathrm{mV} / \mathrm{ppm} \mathrm{U}$.

The mass and elemental bias and mass spectrometer drift of both $\mathrm{U} / \mathrm{Pb}$ and $\mathrm{Pb} / \mathrm{Pb}$ ratios, respectively, were corrected applying the "intercept method" developed by Sylvester and Ghaderi (1997). The calculated ${ }^{206} \mathrm{~Pb} /{ }^{238} \mathrm{U}$ and ${ }^{207} \mathrm{~Pb} /{ }^{206} \mathrm{~Pb}$ intercept values were corrected for mass discrimination from analyses of the Plesovice reference zircon measured during the analytical session using a standard bracketing method (Klötzli et al., 2009). The correction utilises the regression of standard measurements by a quadratic function. A common $\mathrm{Pb}$ correction was applied to the data using the apparent ${ }^{207} \mathrm{~Pb} /{ }^{206} \mathrm{~Pb}$ age and the Stacey and Kramers $\mathrm{Pb}$ evolution model (Stacey and Kramers, 1975). Final age calculations were per- formed with Isoplot( 3.0 (Ludwig, 2003). All errors reported for LA data are at the 2-sigma level.

The Plešovice reference zircon (Sláma et al., 2008) was also used as secondary standard in order to test the overall reproducibility of the analytical method. A total of 13 measurements made during the analytical session resulted in a concordia age of $337.1 \pm 0.6 \mathrm{Ma}(2 \sigma$, decayconstant errors included, MSWD concordance $=0.21$, probability of concordance $=0.64$ ). This is within error identical to the accepted reference ${ }^{206} \mathrm{~Pb} /{ }^{238} \mathrm{U}$ date of $337.13 \pm 0.37 \mathrm{Ma}$ (Sláma et al., 2008).

Mineral abbreviations used here follow those used by Slovenec and Bermanec (2003).

\section{RESULTS}

\section{Sample macroscopic and microscopic description}

\section{PSG-1 sample - Omanovac Quarry, Psunj Mt.}

The PSG-1 sample originates from a homogeneous granitic body from Omanovac Quarry in the Rogoljica Valley (W Psunj Mt) (Fig. 1B). The representative sample is shown on Fig. 2A. The main mineral constituents include K-feldspar, quartz and amphibole. Plagioclase is present in small amounts (Fig. 2B). K-feldspars (Fig. 2C) are represented by a microcline that shows polysynthetic twinning. Perthite intergrowths are common. The microcline contains inclusions of quartz and relics of plagioclase. Quartz is allotriomorphic, with undulatory extinction, and fills the interstices between K-feldspars and amphibole (Fig. 2D). Accessory minerals are zircon, allanite and Ce-epidote.
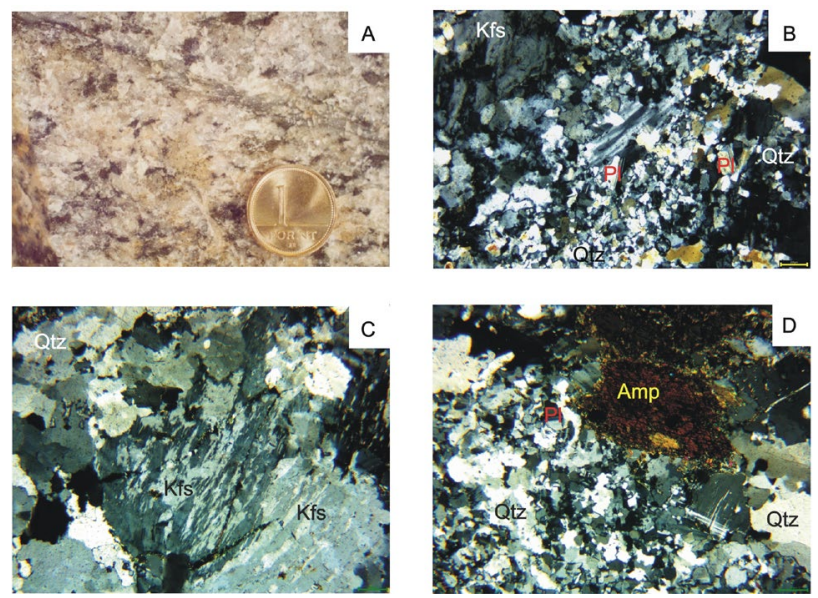

Fig. 2. Representative sample (PSG-1) from Omanovac Quarry (Psunj Mt., Croatia): $A$ - macrophotography (R coin $=16 \mathrm{~mm}) ; B-D$ microphotographs (crossed nicols). Abbreviations: Qtz - quartz, Kfs - Kfeldspar, PI-plagioclase, Amp - amphibole. 
No biotite is found in the PSG-1 sample, and plagioclase occurs in small amounts. Plagioclase is almost pure albite (0.5 mol\% Or, 98-97 mol\% Ab, 1-2 mol\% An). The average K-feldspar composition is $96 \mathrm{~mol} \%$ Or, $4 \mathrm{~mol} \mathrm{\%} \mathrm{Ab,} 0 \mathrm{~mol} \% \mathrm{An}$. The amphibole is a ferrohornblende (Horvat and Buda, 2004). The PSG-1 sample is classified as amphibole monzogranite according to A-P-Q ternary classification diagram for plutonic rocks (IUGS, 1973), and as monzogranite in the chemicalmineralogical classification of Debon and Le Fort (1983) $(\mathrm{Q}=199, \mathrm{P}=-39)$. It has a relatively high concentration of REE (330 ppm), with a strong negative $\mathrm{Sr}$ and Eu anomaly. Elevated $\Sigma$ REE and a negative Eu anomaly indicate a typical magmatic fractional crystallisation of this monzogranite (Horvat et al., 2015a).

\section{PPG-32 sample - Šandrovac Quarry, Papuk Mt.}

The 2PPG-32 sample is from Šandrovac Quarry (NW Papuk Mt) (Fig. 1B). The representative sample is shown in Fig. 3A.The main mineral phases are: grey quartz, white or greenish feldspar, biotite and pale yellow muscovite with pearl brightness. K-feldspars (Fig. 3B, 3C) are maximum microcline on the basis of XRD data (Horvat et al., 2011), and plagioclase is the oligoclase according to the composition obtained by electron microprobe (2-3 mol \% Or 73-80 mol\% Ab $17-24 \mathrm{~mol} \%$ An; Horvat and Buda, 2004). Muscovite is developed in allotriomorphic leaves (Fig. 3B, 3D). It can be found in plagioclase (Fig. 3C) as inclusion but also as a rock constituent. Biotite is fully chloritised (Fig. 3B). Accessory minerals are zircon, monazite, REE-carbonates, Fe-oxides and garnet. The 2PPG-32 sample is classified as muscovite-biotite monzogranite according to modal mineral content (Horvat and Buda, 2004), and as monzogranite
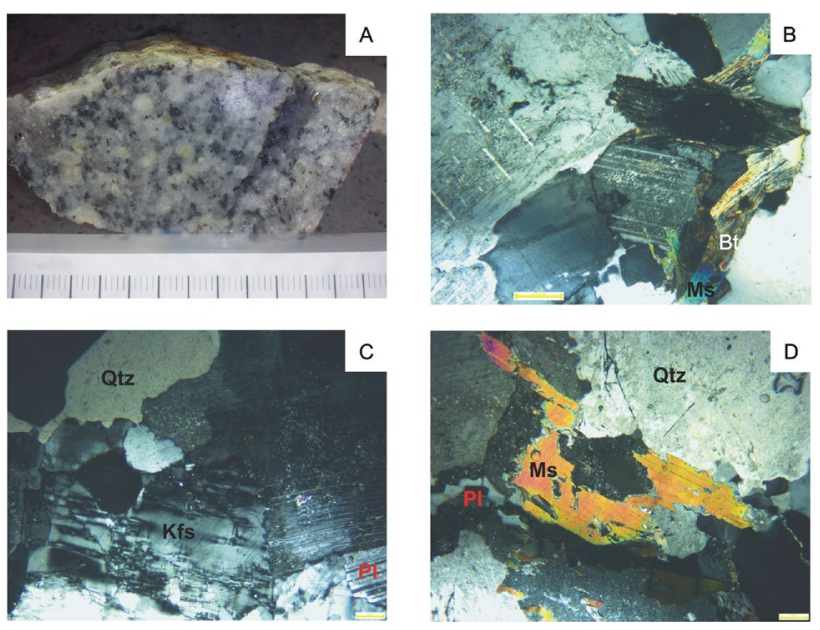

Fig. 3. . Representative sample (2PPG-32) from Šandrovac Quarry (Papuk Mt., Croatia): A - macrophotography (scale in cm); B-D microphotographs (crossed nicols). Abbreviations: Qtz - quartz, Kfs - K-feldspar, PI-plagioclase, Bi - biotite, Ms - muscovite. according to the parameters $\mathrm{Q}=175$ and $\mathrm{P}=-68$ in the multicationic classification diagram by Debon and Le Fort (1983). The total REE concentration is relatively high (120 ppm), with strong negative $\mathrm{Eu}, \mathrm{Ti}, \mathrm{Sr}$ and $\mathrm{Nb}$ anomalies. Elevated $\Sigma$ REE and a negative Eu anomaly indicate typical magmatic fractional crystallisation of this monzogranite (Horvat et al., 2015b).

\section{HEG-31 sample - Kišeljevac Creek, Papuk Mt.}

The HEG-31 sample is from a magmatic body in the gneiss zone at the $\mathrm{S}$ slope of Papuk Mt. (Fig. 1B) in Kišeljevac Creek. The main mineral phases are: grey quartz, white or greenish feldspar and biotite. The structure is homogeneous. A granophyric texture is observed (Fig. 4B) as an intergrowth of quartz and alkali feldspar. Two K-feldspars can be distinguished (Fig. 4A, 4B): orthoclase and low microcline with high $\mathrm{Al}$ content in the T1o site (0.98) (Horvat et al., 2011). The plagioclase is oligoclase (1 mol\% Or 80-75 mol\% Ab 18-24 mol\% An; Horvat and Buda, 2004). Biotite is characterised by strong pleochroism ranging from yellowish-brown to reddish brown and regularly includes zircon and/or monazite crystals (Fig. 4C, 4D). The reddish colour may indicate increased titanium content. Accessory minerals are garnet, apatite, zircon and monazite. The HEG-31 sample is classified as biotite monzogranite (Horvat and Buda, 2004) according to modal mineral content and nomenclature diagram for igneous rocks (IUGS, 1973). The multicationic classification (Debon and Le Fort, 1983) parameters are $\mathrm{Q}=173$ and $\mathrm{P}=-53$. The REE pattern is V-shaped (concave down), indicating enrichment in both, HREE and LREE. The REE concentration is relatively high $(223 \mathrm{ppm})$, with a slight negative Eu anomaly (Horvat and Buda, 2004).
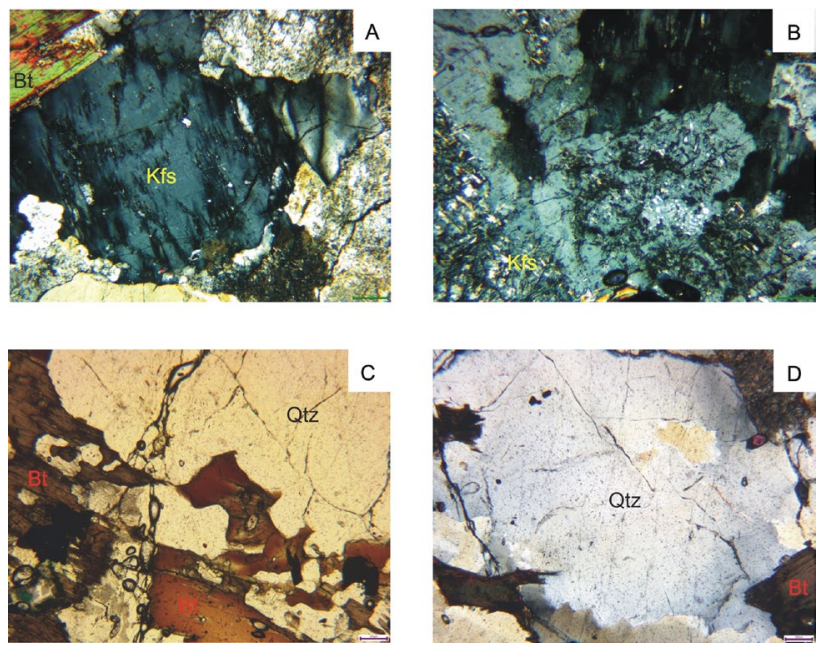

Fig. 4. Representative sample (HEG-31) from Kišeljevac Creek (Papuk Mt., Croatia): A-D microphotographs (crossed nicols). Abbreviations: Qtz - quartz, Kfs - K-feldspar, Bt - biotite. 


\section{Zircon characteristics and $\mathbf{U}-\mathbf{P b}$ dating}

\section{PSG-1 sample zircons}

Zircon grain sizes from the PSG-1 sample vary from 70 to 120 microns in length, with aspect ratios of 1:2. Zircon crystals are subhedral, colourless and clear, with distinct internal zonation features: CL dark, idiomorphic, sometimes rounded cores are followed by a CL bright to dark alteration zone or a dark alteration zone which is sometimes zoned (Fig. 5). The CL image reveals the oscillatory zoning pattern. The white rectangles and circles mark the in-situ laser-ablation track $(\varnothing=10-15$ $20 \mu \mathrm{m}$ ). The respective $\mathrm{U}-\mathrm{Pb}$ isotopic data are reported in Table 1. Nine measurements define a poorly constrained concordia age of $380 \pm 4$ Ma (Fig. 6; Table 1).

\section{PPG-32 sample zircons}

Zircon crystals from the $2 \mathrm{PPG}-32$ sample are euhedral, long-prismatic, with grain size from 100 to 150 micron in length, with aspect ratios of 1:2. CL images of sections through zircon crystals reveal a typically magmatic zircon with oscillatory zoning, plus different alteration rims (zones) in the zircon grains. Within the oscilla- tory zonation one, two or even three CL-dark zones can be distinguished (Fig. 7). Also, some crystals have a CL-dark outer alteration zone. There is a characteristic CL-bright rim inwards to the altered zone. The white rectangles mark the in-situ laser-ablation track $(\varnothing=10$ 15 microns), and corresponding U-Th- $\mathrm{Pb}$ analytical results are shown in Table 1. Seven measurements yielded a concordia age of $382 \pm 2 \mathrm{Ma}$ (Fig. 8).

\section{HEG-31 sample zircons}

Zircon grains sizes from the HEG-31 sample vary in length from 70 to 130 microns. Zircon crystals are euhedral to subhedral, both long- and short prismatic, with aspect ratios of 1:2 to 1:3 (Fig. 9). Three (3) crystals have inherited cores (typical S-type granitoid core), but most of them are without significant core. The grains show typical oscillatory zoning, and CL-dark inside and CL-dark outside rims. Isotopic data for 18 zircon grains include 10 analyses of alteration zone. The white rectangles and circles mark the in-situ laser-ablation track $(\varnothing=$ $10-15-20 \mu \mathrm{m})$. A total of 20 measurements (Table 1) defined a lower intercept age of $383 \pm 5 \mathrm{Ma}$ (Fig. 10, with a forced upper intercept at $\left.{ }^{207} \mathrm{~Pb} /{ }^{206} \mathrm{~Pb}=0.85 \pm 0.05\right)$.
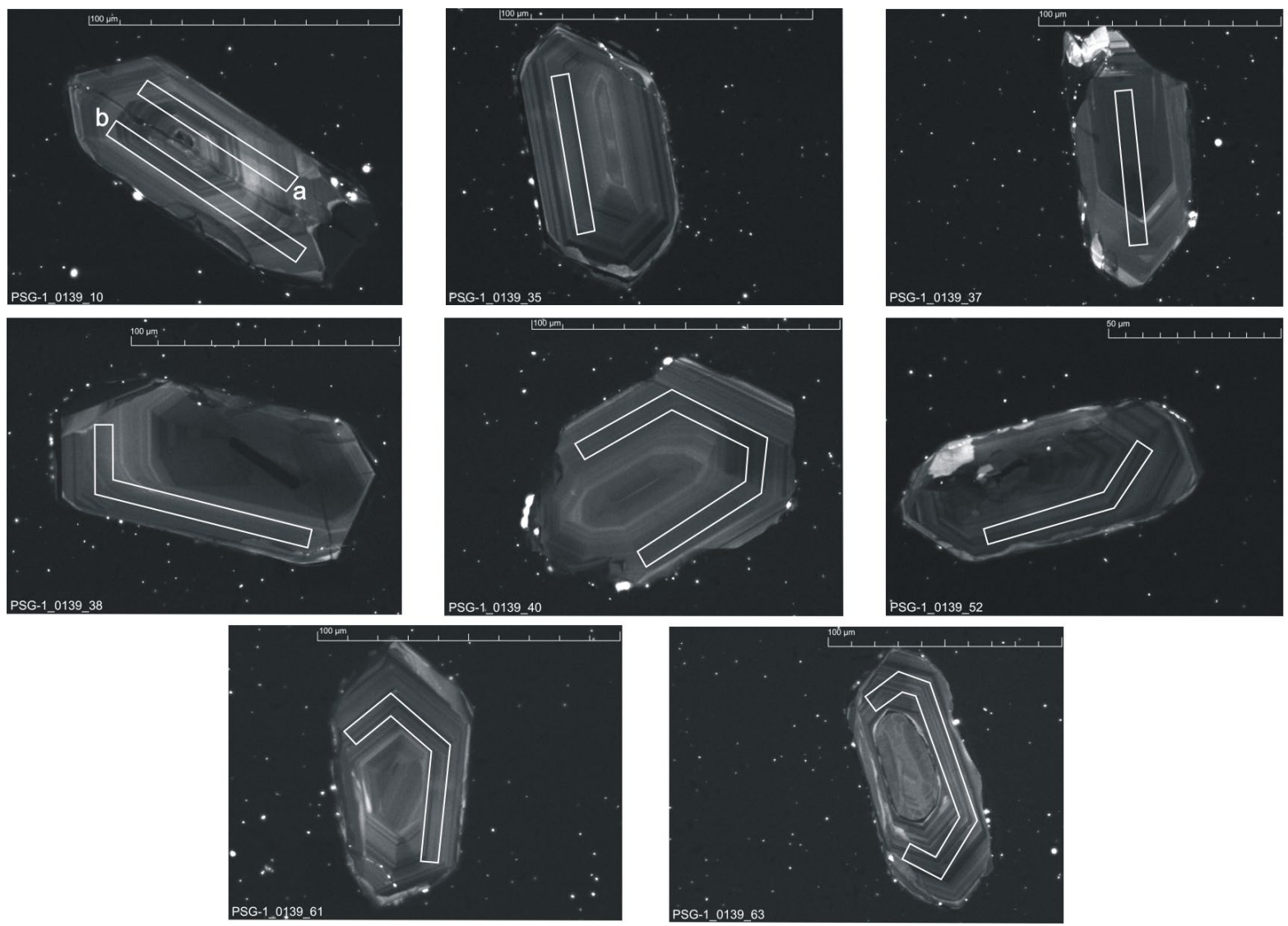

Fig. 5. Cathodoluminescence images of dated zircon crystals separated from the amphibole monzogranite (PSG-1) from Omanovac Quarry, Psunj Mt., Croatia. The white rectangles and circles mark the in-situ laser-ablation track used for U/Pb dating, $(\varnothing=10-15-20 \mu \mathrm{m})$, and they are not in scale. Measurement numbers are listed in Table 1. 


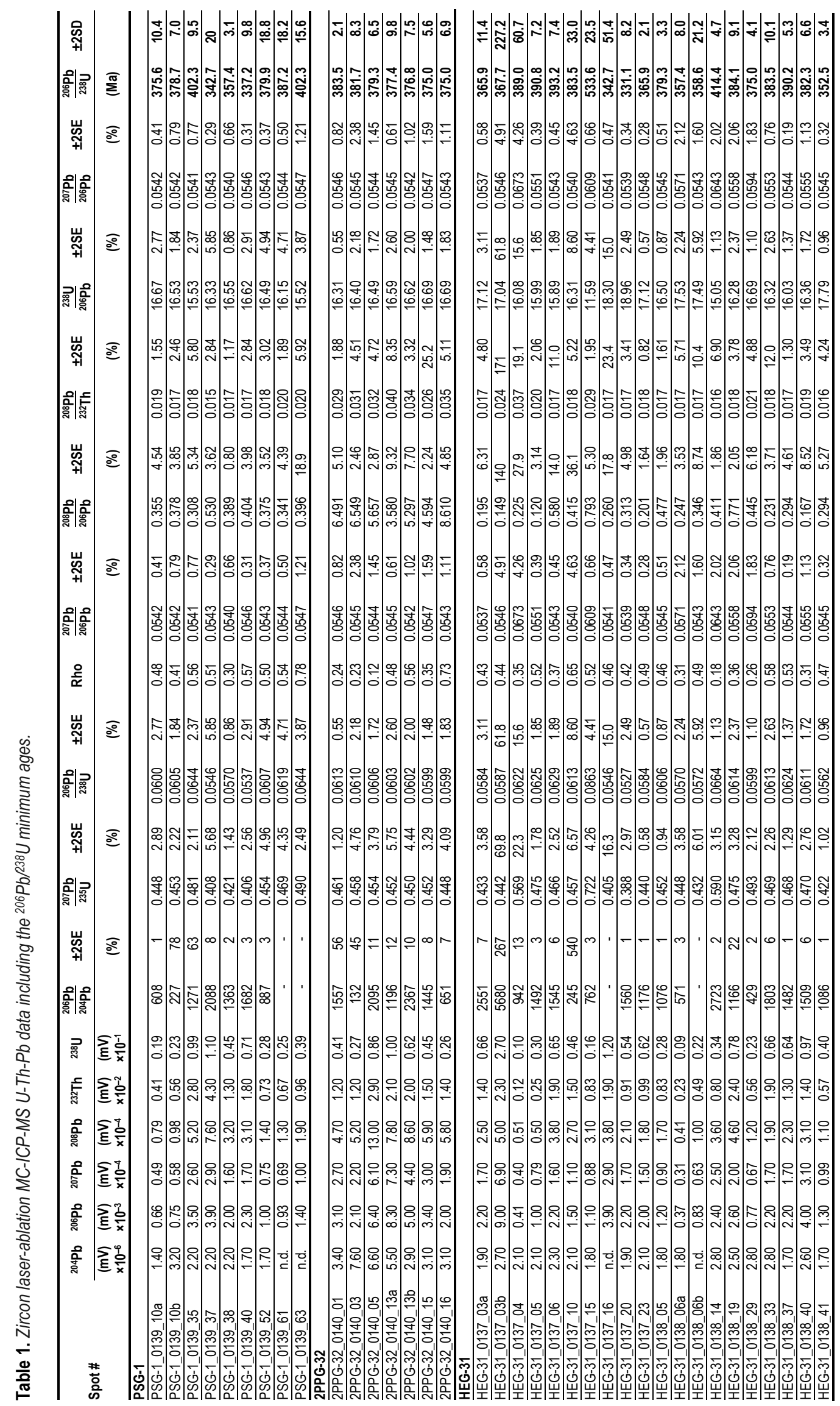




\section{DISCUSSION}

The oldest exposed rocks of the Slavonian Mts. occur in the Psunj-Krndija Complex according to research by Jamičić (1988; 1989; 2001), and this was confirmed by recent data by Balen and co-authors (2006; 2013; 2015). Different types of granitoids and gabbro intrusions are associated with these metamorphic rocks, but large amounts of granite are also found in the Papuk Complex (Jamičić et al., 1987, 1989) (Fig. 1B). Pamić and Lanphere (1991) and Pamić et al. (1996) distinguished two genetically different types of granitoids: S-type granitoids occur together with migmatites and are presumed to have arisen from a progressive metamorphic sequence in lower continental crust, while I-type intruded into a Barrow-type progressive sequence thought to be formed during the Variscan orogeny. Pamić et al. (1988a) concluded that all metamorphic and associated igneous rocks from Mts. Papuk, Psunj and Krndija in Slavonia were produced during the Hercynian orogeny.

The PSG-1 sample is from a granitic body in the Rogoljica Valley in the western part of Psunj Mt. (Fig. 1B), where the granitoids were emplaced in amphibolitesfacies rocks. Marci (1965) described granitic rocks as non-cataclastic and cataclastic leucocratic granites in association with amphibolites, amphibole-zoisite-chlorite schists and leucocratic amphibole-bearing gneisses. The boundary between granites and amphibolites is formed by amphibole-biotite schists (Tajder, 1966 and Marci, 1971). Marci (1973) argued that magma had a uniform composition with a crystallisation sequence: plagioclase - biotite quartz - microcline - perthitic microcline. It was assumed that the granitic melt crystallised probably as a last differ-

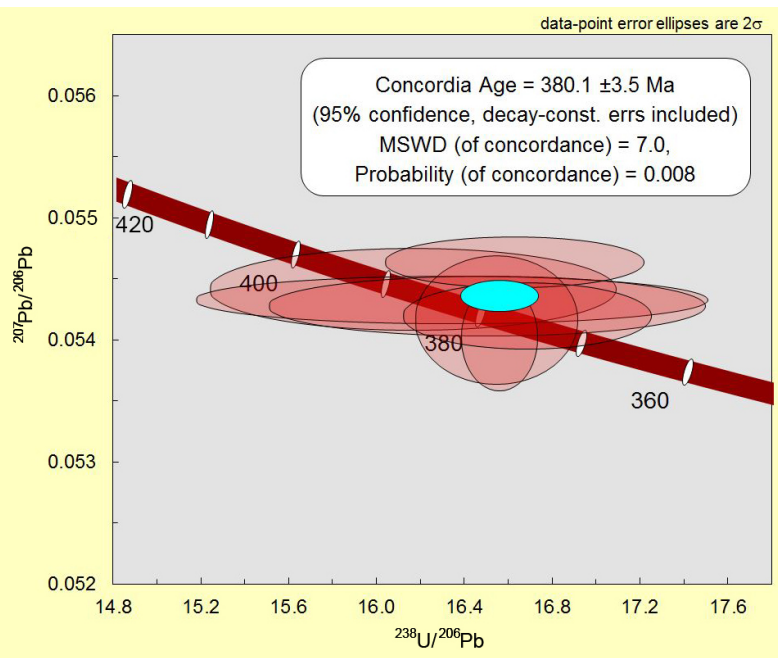

Fig. 6. Concordia plot of LA-MC-ICP-MS U-Pb zircon analytical results for the PSG-1 sample.

entiate of a granodioritic melt. Horvat and Buda (2004) discussed the type rich in quartz and K-feldspar from Omanovac Quarry. According to the normative composition and Q' and ANOR parameters, the PSG-1 sample is alkali feldspar granite, and according to the IUGS classification (1973), it is an amphibole monzogranite (data from Table 3, Horvat and Buda, 2004). Chappell and White (1974) suggested two types of granite: S-type (sedimentary or supracrustal) and I-type (igneous or infracrustal) that come from source rocks of fundamentally different origin - one formed by deposition on the crust, the other by accretion beneath the crust. Chappell and
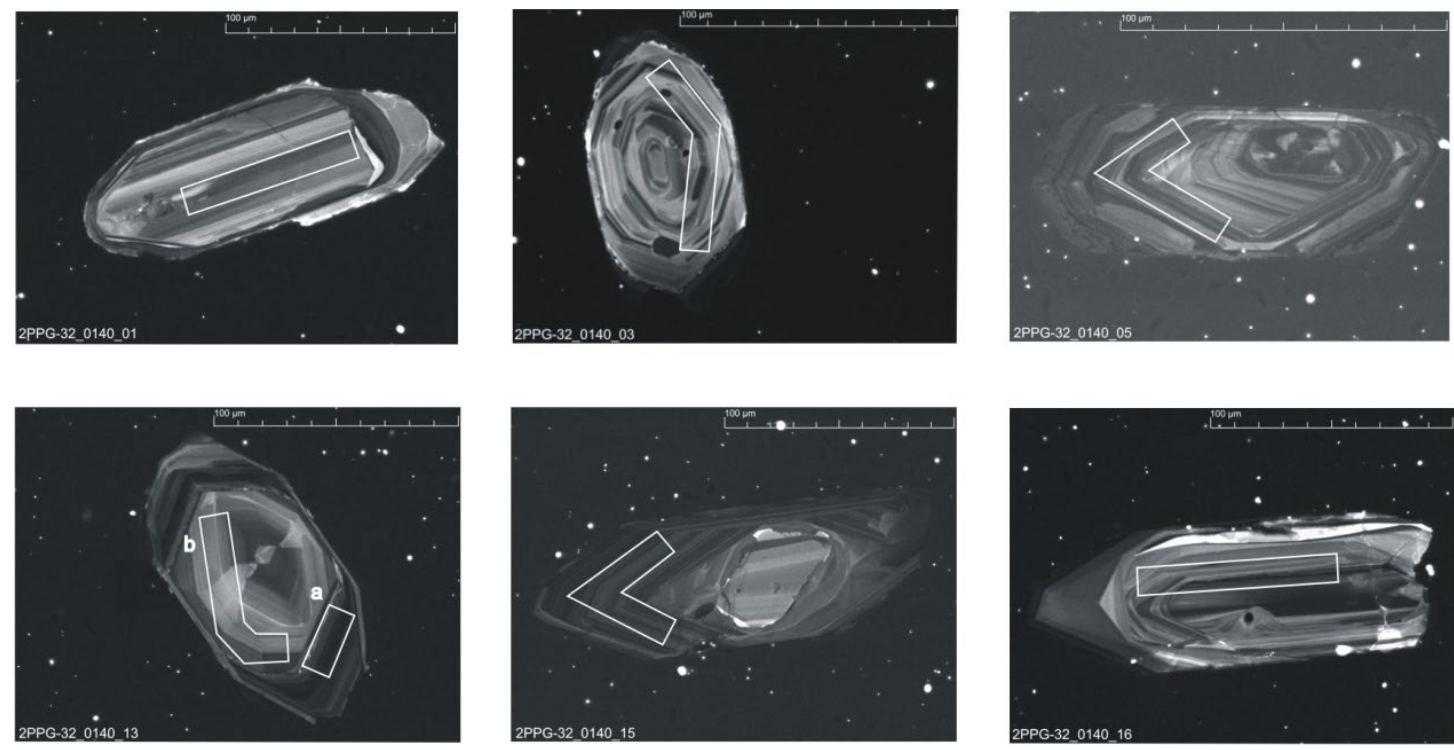

Fig. 7. Cathodoluminescence images of dated zircon crystals separated from the monzogranite (2PPG-32) from Šandrovac Quarry, Papuk Mt., Croatia. The white rectangles mark the in-situ laser-ablation track used for U/Pb dating, $(\varnothing=10-15 \mu \mathrm{m})$ and they are not in scale. Measurement numbers are listed in Table 1. 


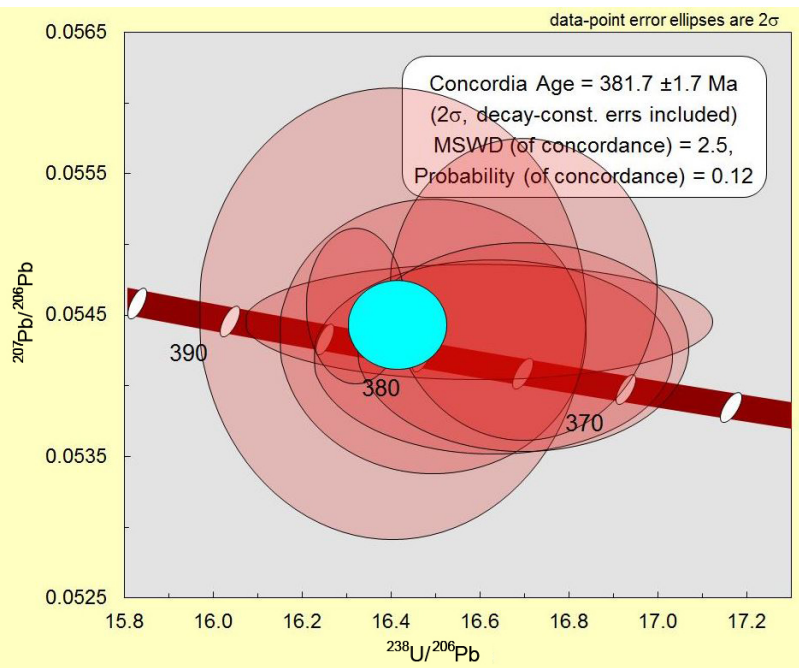

Fig. 8. Concordia plots of LA-MC-ICP-MS U-Pb zircon analytical results (Table 1) for the 2PPG-32 sample.

White (1984) gave Na the role to distinguish between the I- and S-type granites. The wt $\% \mathrm{Na}_{2} \mathrm{O}$ content is higher than 3.2 in salic varieties and decreasing to 2.2 in more femic types. The line that was given as a boundary between the two types joins the points $2 \mathrm{wt} \% \mathrm{~K}_{2} \mathrm{O}, 2 \mathrm{wt} \%$ $\mathrm{Na}_{2} \mathrm{O}$ and 5 wt $\% \mathrm{~K}_{2} \mathrm{O}, 3.5 \mathrm{wt} \% \mathrm{Na}_{2} \mathrm{O}$. The wt $\% \mathrm{~K}_{2} \mathrm{O}$ versus wt $\% \mathrm{Na}_{2} \mathrm{O}$ content equal to approximately 0.90 (Chappell and White, 1984), and the relationship between the $\mathrm{wt} \% \mathrm{SiO}_{2}$ content and the alumina-saturation index (ASI) ([molar $\left.\mathrm{Al}_{2} \mathrm{O}_{3} /\left(\mathrm{CaO}+\mathrm{Na}_{2} \mathrm{O}+\mathrm{K}_{2} \mathrm{O}\right)\right]$ Shand (1927)) equal to 1.01 , indicating I-type origin for this particular sample. According to the alumina saturation index (ASI) and the $\mathrm{A} / \mathrm{NK}$, the molar ratio cannot discriminate between peraluminous and metaluminous geochemical affinity. This classification is in accordance with the petrographic observations that PSG-1 contains amphibole in addition to biotite and/or epidote and/or titanite.

The 2PPG-32 sample is from Šandrovac Quarry in the NW part of the Mt. Papuk, where basalts and andesites dykes (Lugović, 1983) intersect various metamorphic rocks ranging from the chlorite- to amphibolite-facies in association with different varieties of granitic rocks (Jamičić, 1989). This muscovite-biotite monzogranite has a eutectic composition and a peraluminous character (ASI $=1.20$ ) (Horvat and Buda, 2004). The analysed sample has a $\mathrm{Na}_{2} \mathrm{O}$ content of 3.92 and a $\mathrm{K}_{2} \mathrm{O}$ content of 3.80 , and belongs to the I-type according to the Chappell and White (1984) criteria. The relationship between the wt $\%$ $\mathrm{SiO}_{2}$ content and the aluminium saturation index (ASI = 1.20 ) for the 2PPG-32 sample suggested an S-type character.

The HEG-31 sample, biotite monzogranite from the Kišeljevac Creek valley (the S slope of Papuk Mt.) is the small granitoid intrusion found within the gneiss, with significant contact aureole and marble formation. This field observation confirmed the intrusion of siliceous melt, for which it was determined as having a peraluminous character $(\mathrm{ASI}=1.08)$. The analysed sample has a $3.36 \mathrm{wt} \% \mathrm{Na}_{2} \mathrm{O}$ content and a $4.30 \mathrm{wt} \% \mathrm{~K}_{2} \mathrm{O}$ content, and belongs to the transitive zone between the S- and I-type according to Chapell and White (1984) criteria. Biotite in this sample is red-brown in colour (Fig. 4C), which is characteristic for the I-type granites that are reduced (Chappell and White, 2001).

It can be assumed that the monzogranite rocks in question cannot be classified as strictly S- or I- type (Pamić et al., 1996 and Pamić and Jurković, 2002).

The first $\mathrm{K}-\mathrm{Ar}$ and $\mathrm{Rb}-\mathrm{Sr}$ ages for metamorphic and associated igneous rocks from Mts. Papuk, Psunj and Krndija in Slavonia were reported by Pamić et al. (1988a and references therein). Particular data reported in Pamić et al. (1988a), compared to samples present in this work, are $155.2 \pm 3.7 \mathrm{Ma} \mathrm{K}$-Ar ages for biotite-hornblende granite from Rogoljica (W Psunj Mt.) on hornblende and $93.6 \pm 2.3 \mathrm{Ma}$ on biotite; $335.2 \pm 8.4 \mathrm{Ma} \mathrm{K}$-Ar ages for pegmatite from the Šandrovac location (the NW part of the Papuk Mt.) on muscovite and $321.5 \pm 8$ Ma K-Ar ages for Bi-granite from Kišeljevac (the $\mathrm{S}$ slope of Papuk Mt.) on biotite. The same authors obtained two groups of older ages from 421 to $658 \mathrm{Ma}$ and from 352 to $376 \mathrm{Ma}$ on hornblende from amphibolites (K-Ar measurements). These discordant ages were subsequently checked by ${ }^{40} \mathrm{Ar}-{ }^{39} \mathrm{Ar}$ spectra measurements on muscovite and biotite from paragneisses and mica schists. In five from seven ages ranging between 337 and $321 \mathrm{Ma}$, one sample yielded $264 \mathrm{Ma}$ and one $430 \mathrm{Ma}$ (Pamić et al., 1996). Radiometric age determinations were carried out on granitoids from surface and boreholes by Pamić and Lanphere (1991), and yielded two groups of ages: K-Ar measurements on hornblende, biotite and muscovite yielded ages from 338.9 to $321.5 \mathrm{Ma}$ and from 223.3 to $93.5 \mathrm{Ma}$, respectively. The younger ages were interpreted as stemming from Ar loss during the Alpine orogeny. The same authors in the same paper published the Sr-evolution diagram on whole-rock samples with an isochron age of $314 \mathrm{Ma}$. K-Ar dating of hornblende is an outdated method and much of the published data is not reliable in modern views. This is because hornblendes usually contain significant amounts of excess Ar, resulting in too old ages. Both the $\mathrm{Rb}-\mathrm{Sr}$ and $\mathrm{K}-\mathrm{Ar}$ age can be prone to problems with late-stage fluids and deformation. This is especially a problem with older age data which was collected from huge sample sizes (hundreds of milligrams) leading to mixed effects etc. In-situ U-Pb dating is the most reliable method used for establishing the absolute time constraints of the temporal evolution of magmatic and metamorphic rocks. LA ICP-MS (Laser Ablation Inductively Coupled Plasma Mass Spectrometry) allows for a highly sensitive elemental and isotopic analysis to be performed directly on solid samples. This kind of modern technology is crucial and irreplaceable for isotopic analysis of small mineral grains, and the best way to investigate the 

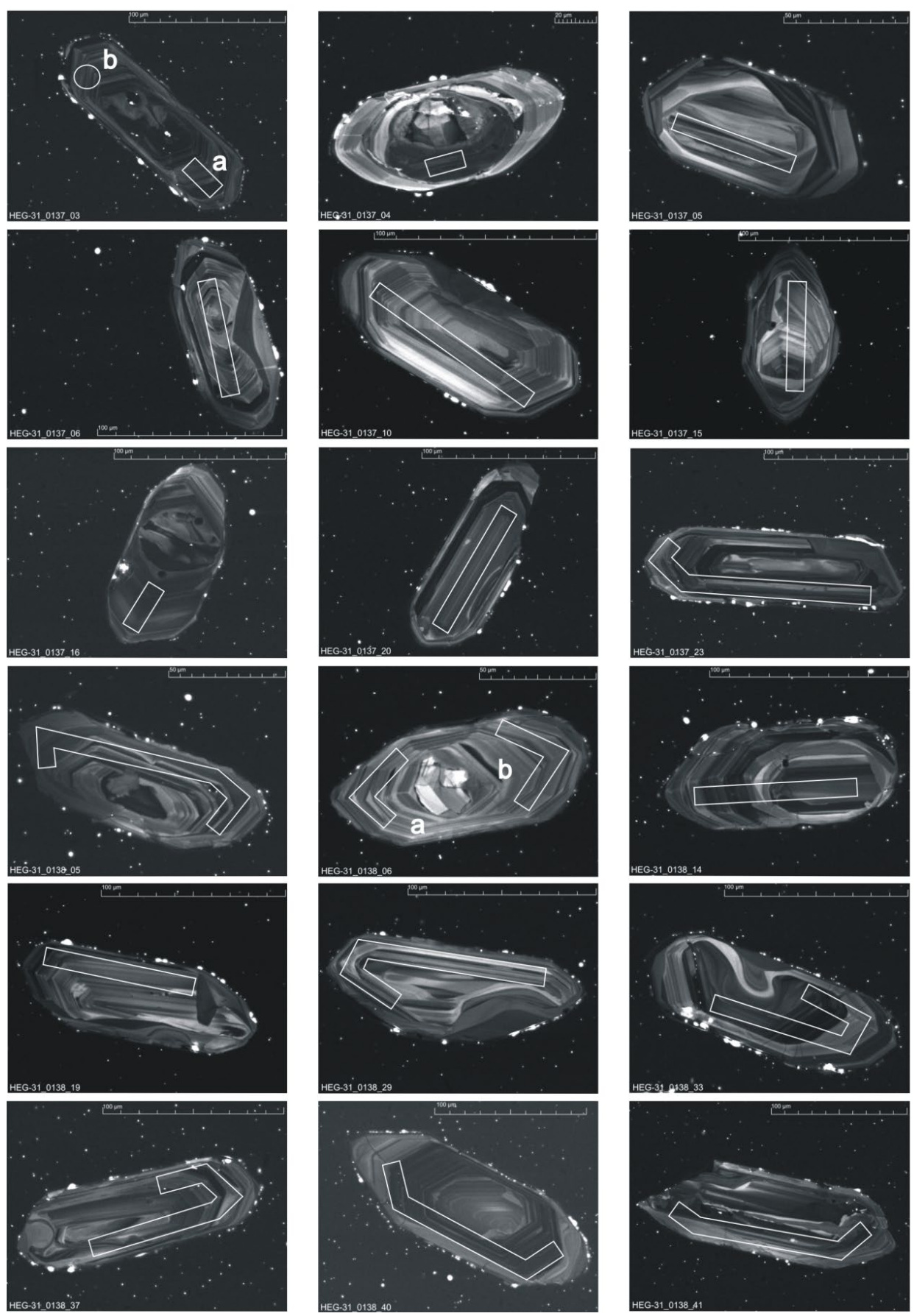

Fig. 9. Cathodoluminescence images of dated zircon crystals separated from the biotite monzogranite (HEG-31) from Kišeljevac Creek, Papuk Mt., Croatia. The white rectangles mark the in-situ laser-ablation track used for U/Pb dating, $(\varnothing=10-15-20 \mu \mathrm{m})$, and they are not in scale. Measurement numbers are listed in Table 1.

geological history of old crystalline rocks, in order to understand and date the processes which affected regional geological setting.

The application of the in-situ laser ablation U-Pb zircon dating method provides the absolute rock ages of one sample from the Papuk Complex (2PPG-32, Šandrovac
Quarry, Papuk Mt.) and two samples from the PsunjKrndija Complex (PSG-1, Omanovac Quarry, Psunj Mt. and HEG-31, Kišeljevac Creek, Papuk Mt.). The cathodoluminescence images reveal the oscillatory zoning pattern through all zircon crystals, which are interpreted as stemming from magmatic zircon growth from a silicic 


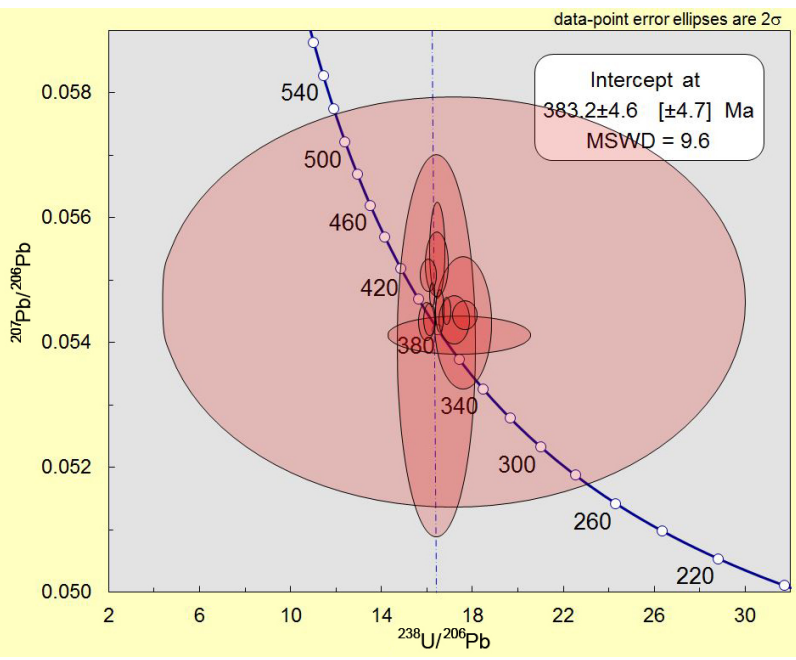

Fig. 10. Concordia plots of LA-MC-ICP-MS U-Pb zircon analytical results (Table 1) for the HEG-31 sample (calculated with a forced upper intercept at ${ }^{207} \mathrm{~Pb} / 206 \mathrm{~Pb}=0.85 \pm 0.05$ ).

melt. The U-Pb results for all three representative granitoid samples from different intrusive bodies are, therefore, interpreted to represent intrusion ages: $380 \pm 4 \mathrm{Ma}$ for the monzogranite from Omanovac Quarry (W Psunj Mt.), $382 \pm 2$ Ma for the monzogranite from Šandrovac Quarry (NW Papuk Mt.) and $383 \pm 5 \mathrm{Ma}$ for the monzogranite from Kišeljevac Creek (S slope of Papuk Mt.).

These results suggest Late Devonian magmatic activity, and show that the investigated granitoid intrusions had occurred earlier than previous radiometric studies have suggested.

\section{CONCLUSIONS}

In-situ LA-MC-ICP-MS U-Pb zircon dating provides following new geochronological insights into the evolution of crystalline rocks of the Slavonian Mts. - Psunj and Papuk:

1) $380 \pm 4 \mathrm{Ma}$ intrusion age of the monzogranite from Omanovac Quarry, Psunj Mt.

2) $382 \pm 2 \mathrm{Ma}$ intrusion age of the monzogranite from Šandrovac Quarry, Papuk Mt. and

3) $383 \pm 5 \mathrm{Ma}$ intrusion age of the monzogranite from Kišeljevac Creek, Papuk Mt.

The study showed that the granitoid intrusions in question had occurred earlier (in Late Devonian) than previous radiometric studies have reported, confirming multistage granitoid magmatism in the Slavonian Mts. The pre-Variscan elements are a relevant fact, hidden by Variscan and Alpine marks. As relics, they occur today as poly-metamorphic and migmatite domains in the Slavonian Mts. in Croatia.

\section{ACKNOWLEDGEMENTS}

This work was financed by Ministry of Science and Education of the Republic of Croatia, and supported by OTKA (Hungarian National Research Fund project no. K 67787). The study was carried out partly at the Department of Mineralogy, Eötvös Loránd University, Budapest, and was supported by the Hungarian Ministry of Education through the Ph.D. scholarship of the first author. The study was also carried out at the Department of Geology of the Croatian Geological Survey, as well as at the Department of Lithospheric Research, the University of Vienna, the Department of Earth Sciences, KarlFranzens-Universität Graz and the Institute of Applied Geosciences, the Graz Technical University. The authors are very grateful to †Livia Rudnyánszky (Department of Mineralogy, Eötvös Loránd University) for zircon separation and Franz Biedermann (Department of Lithospheric Research, University of Vienna) for the preparation of BSE/CL images. The authors would also like to acknowledge Mirko Belak (Department of Geology, Croatian Geological Survey) for useful discussion. Special thanks go to Christian Auer (Geological Survey of Austria, Vienna) for scanning electron microscopy facilities. The authors would like to thank to three anonymous reviewers for their constructive comments, objections and suggestions which have contributed in the reorganization and improvement of the manuscript.

\section{REFERENCES}

Balen D, Horváth P, Tomljenović T, Finger F, Humer B, Pamić J and Árkai P, 2006. A record of pre-Variscan Barrovian regional metamorphism in the eastern part of the Slavonian Mountains (NE Croatia). Mineralogy and Petrology 87: 143-162, DOI 10.1007/s00710-006-0120-1.

Balen D, Horváth P, Finger F and Starijaš B, 2013. Phase equilibrium, geothermobarometric and xenotime age dating constraints on the Alpine metamorphism recorded in chloritoid schists from the southern part of the Tisia Mega-Unit (Slavonian Mts., NE Croatia). International Journal of Earth Sciences 102: 1091-1109, DOI 10.1007/s00531-012-0850-8.

Balen D, Massonne H-J and Petrinec Z, 2015. Collision-related Early Paleozoic evolution of a crustal fragment from the northern Gondwana margin (Slavonian Mountains, Tisia Mega-Unit Croatia): Reconstruction of the $\mathrm{P}-\mathrm{T}$ path, timing and paleotectonic implications, Lithos 232: 211-228, DOI 10.1016/j.lithos.2015.07.003.

Balla Z, 1986. Analysis of the anti-clockwise rotation of the Mecsek Mountains (Southwest Hungary) in the Cretaceous: interpretation of paleomagnetic data in the light of the geology. Geophysical Transactions 32(2):147-181.

Biševac V, Balogh K, Balen D and Tibljaš, D, 2010. Alpine (Cretaceous) very low- to low-grade metamorphism recorded on the illite-muscovite-rich fraction of metasedimentsfrom South Tisia (eastern Mt Papuk, Croatia). Geologica Carpathica 61: 469-481, DOI 10.2478/v10096-010-0029-9.

Biševac V, Krenn E, Finger F, Lužar-Oberiter B and Balen D, 2013. Provenance of Palaeozoic very low- to low-grade metasedimentary rocks of south Tisia (Slavonian Mountains, Radlovac complex, Croatia). Geologica Carpathica 64: 3-22, DOI 10.2478/geoca2013-0001. 
Bleahu M, Mantea G, Bordea S, Panin S, Stephanescu M, Šikić K, Haas J, Kovács S, Péró Cs, Bérczi-Makk Á, Konrád Gy, Nagy E, Rálisch-Felgenhauer E and Török Á, 1996. Triassic facies types, evolutions and paleogeographic relations of Tisza Megaunit. Acta Geologica Hungarica 37(3-4):187-234.

Brkić M, Jamičić D and Pantić N, 1974. Karbonske naslage u Papuku (sjeveroistočna Hrvatska) (Carboniferous deposits in Papuk Mountain - Northeastern Croatia). Geološki vjesnik 27: 53-58 (in Croatian).

Chappell BW and White AJR, 1974. Two contrasting granite types. Pacific Geology 8: 173-174.

Chappell BW and White AJR, 1984. I- and S-type granites in the Lachlan Fold Belt, south-eastern Australia. In: Keqin X and Guangchi T, eds., Geology of granites and their metallogenic relations. Science Press, Beijing, 87-101.

Chappell BW and White AJR, 2001. Two contrasting granite types: 25 years later. Australian Journal of Earth Sciences 48(4): 489-499, DOI 10.1046/j.1440-0952.2001.00882.x.

Csontos L, Nagymarosi A, Horváth F and Kováć M, 1992. Tertiary evolution of the Intracarpathian area: model. Tectonophysics 208: 221-241, DOI 10.1016/0040-1951(92)90346-8.

Debon F and Le Fort P, 1983. A chemical-mineralogical classification of common plutonic rocks and associations. Transactions of the Royal Society of Edinburgh: Earth Sciences 73: 135-149, DOI 10.1017/S0263593300010117.

de la Roche H, Leterrier J, Grandclaude P and Marchal M, 1980. A classification of volcanic and plutonic rocks using R1R2-diagram and major element analyses - its relationships with current nomenclature. Chemical Geology 29: 183-210, DOI 10.1016/00092541(80)90020-0.

Ebner F, Vozárová A, Kovács S, Kräutner HG, Krstić B, Szederkényi T, Jamičić D, Balen D, Belak M and Trajanova M, 2008. DevonianCarboniferous pre-flysch and flysch environments in the Circum Pannonian Region. Review. Geologica Carpathica 59(2): 159195.

Haas J, 2015. Geological and Tectonic Background. In: Lóczy D, ed., Landscapes and Landforms of Hungary, World Geomorphological Landscapes. DOI 10.1007/978-3-319-08997-3 2 .

Haas J and Péró Cs, 2004. Mesozoic evolution of the Tisza Mega-unit. International Journal of Earth Sciences 93: 297-313, DOI 10.1007/s00531-004-0384-9.

Horvat M and Buda Gy, 2004. Geochemistry and Petrology of some Granitoids from Papuk and Psunj Slavonian Mountains (Croatia). Acta Mineralogica-Petrographica 45(1): 93-100.

Horvat M, Kovács Kis V and Dódony I, 2002. Crystallization path of Kfeldspar megacrysts from Mt. Papuk, Croatia. Geologica Carpathica (special issue) 53: 189-190.

Horvat M, Tibljaš D, Buda Gy and Lovas Gy, 2011. X-ray study of potassium feldspars from different granitoid types and gneisses of Papuk Mt. (Slavonia, Croatia). Geologia Croatica 64(2): 153-162, DOI 10.4154/gc.2011.13.

Horvat M, Klötzli U, Klötzli E, Jamičić D and Buda Gy, 2015a. Magmatic formation/intrusion age of monzogranite from Omanovac Quarry, Psunj Mt., Croatia. In: Horvat $\mathrm{M}$ and Wacha L, eds., $A b$ stracts Book, 4th Croatian Geological Congress, 14-15.10.2010. Šibenik, 111-112.

Horvat M, Klötzli U, Klötzli E, Jamičić D and Buda Gy, 2015b. Magmatic formation/intrusion age of monzogranite from Šandrovac Quarry, NW Papuk Mt., Croatia. MinPet 2015, September $10^{\text {th }}-13^{\text {th }}$ Leoben, Austria, Abstracts. Mitteilungen der Österreichischen Mineralogischen Gesellschaft 161: 52-52.

Horváth F, 1993. Towards a mechanical model for the formation of the Pannonian Basin. Tectonophysics 226: 333-357, DOI 10.1016/0040-1951(93)90126-5.

Horváth P, Balen D, Finger F, Tomljenović B and Krenn E, 2010. Contrasting P-T-t paths from the basement of the Tisia Unit (Slavonian Mts., NE Croatia): application of quantitative phase diagrams and monazite age dating. Lithos 117: 269-282, DOI 10.1016/j.lithos.2010.03.004.

IUGS Subcommission on the Systematics of Igneous Rocks, 1973.
Classification and Nomenclature of Plutonic Rocks Recommendations. Neues Jahrbuch für Mineralogie Monatshefte 4:149-164.

Jamičić D, 1983. Strukturni sklop metamorfnih stijena Krndije i južnih padina Papuka (Structural fabric of the metamorphosed rocks of Mt. Krndija and the eastern part of Mt. Papuk). Geološki vjesnik 36: 51-72 (in Croatian).

Jamičić D, 1988. Strukturni sklop slavonskih planina (sjeverni Psunj, Papuk, Krndija) (Structural pattern of the Slavonian Mountains (Northern Psunj, Papuk, and Krndija)). PhD Thesis, University of Zagreb, 152pp (in Croatian)

Jamičić D, 1989. Osnovna geološka karta SFRJ 1:100000, list Daruvar, L33-95 (Basic Geological Map of SFRY, 1:100000, Daruvar sheet). Geološki zavod Zagreb, Savezni geološki zavod Beograd (in Croatian).

Jamičić D, 2001. Main geological features of the Slavonian Mts. focused to the Našice area. Matica Hrvatska, Našički zbornik 6: 2936 (in Croatian).

Jamičić D and Brkić M, 1987. Osnovna geološka karta SFRJ 1:100000, list Orahovica, L33-96 (Basic Geological Map of SFRY 1:100000, Orahovica sheet). Geološki zavod Zagreb, Savezni geološki zavod Beograd (in Croatian).

Jamičić D, Brkić M, Crnko J and Vragović M, 1987. Osnovna geološka karta SFRJ 1:100000. Tumač za list Orahovica, L33-96 (Explanatory notes for the Basic Geological Map of SFRY 1:100000, Geology of Orahovica sheet). Geološki zavod Zagreb, Savezni geološki zavod Beograd, 72pp (in Croatian).

Jamičić D, Vragović M and Matičec D, 1989. Osnovna geološka karta SFRJ 1:100000. Tumač za list Daruvar, L33-95 (Explanatory notes for the Basic Geological Map of SFRY, 1:100000. Geology of Daruvar sheet). Geološki zavod Zagreb, Savezni geološki zavod Beograd, 55pp (in Croatian)

Klötzli U, Klötzli E, Günes Z and Košler J, 2009. External accuracy of laser ablation $\mathrm{U}-\mathrm{Pb}$ zircon dating: results from a test using five different reference zircons. Geostandards and Geoanalytical Research 33(1): 5-15.

Kovács S, Haas J, Császár G, Szederkényi T, Buda Gy and Nagymarosy A, 2000. Tectonostratigraphic terranes in the pre-Neogene basement of the Hungarian part of the Pannonian area. Acta Geologica Hungarica, 43(3): 225-328.

Kovács Kis V, Horvat M and Dódony I, 2004. Microstructure in Two Alkali Feldspar Megacryst from the Papuk Mt., Croatia. Geologia Croatica 57(2): 149-158.

Ludwig KR, 2003. Isoplot/Ex version 3.00. A geochronological toolkit for Microsoft Excel. Berkeley Geochronology Center. Special Publication No. 4

Lugović B, 1983. Efuzivne stijene sjeverozapadnog dijela Papuka (Extrusive rocks from the NW part of Mt. Papuk (Croatia, Yugoslavia). Geološki vjesnik 36: 131-156 (in Croatian).

Marci V, 1965. Petrografija zapadnog dijela Psunja (Petrography of the western part of Psunj Mountain). Acta geologica IV, Prirodoslovna istraživanja, knjiga 34: 316-322 (in Croatian).

Marci V, 1971. Metasomatski procesi u kontaktnim zonama granita i amfibolita na području Donje Rašaške, Psunj (Metasomatic processes in the granite and amphibolite contact zone in the Donja Rašaška territory, Psunj). Geološki vjesnik 24: 123-131 (in Croatian).

Marci V, 1973. Geneza granitnih stijena Psunja (Genetic aspects of granitic rocks of Psunj). Acta geologica VII/5, Prirodoslovna istraživanja, knjiga 40: 195-231 (in Croatian).

Pamić J, 1988. Stijene granit - granodioritne asocijacije Krndije u Slavoniji (Sjeverna Hrvatska, Jugoslavija) (Rocks off the granite granodiorite association from Mt. Krndija in Slavonia (Northern Croatia, Yugoslavia)). Rad JAZU 441, Razred za prirodne znanosti 23: 97-114 (in Croatian).

Pamić J and Jamičić J, 1986. Metabasic intrusive rocks from the Paleozoic Radlovac complex of Papuk Mt. in Slavonia (northern Croatia, Yugoslavia). Rad JAZU 424:97-127.

Pamić J and Marci V, 1990. Petrology of amphibolites from the Slavonian Mountains in Northern Croatia (Yugoslavia). Geološki vjesnik 43:121-133 (in Croatian). 
Pamić J and Lanphere M, 1991. Hercinske granitne i metamorfne stijene Papuka, Psunja, Krndije i okolne podloge Panonskog bazena u Slavoniji (sjeverna Hrvatska) (Hercynian Granites and Metamorphic Rocks from the Mts. Papuk, Psunj, Krdnija and the Surrounding Basement of the Pannonian Basin in Slavonija (Northern Croatia, Yugoslavia). Geologija 34: 81-253 (in Croatian with English Summary).

Pamić J and Jurković I, 2002. Paleozoic tectonostratigraphic units of the northwest and central Dinarides and the adjoining South Tisia. International Journal of Earth Sciences 91(3): 538-554, DOI 10.1007/s00531-001-0229-8.

Pamić J, Jamičić D and Crnko J, 1984a. Bazične i intermedijarne magmatske stijene iz metamorfita središnjih dijelova Psunja u Slavoniji (Basic and Intermediate Igneous Rocks Associated with Metamorphics of the Middle Parts of Mountain Psunj (Northern Croatia)). Geološki vjesnik 37:127-144 (in Croatian).

Pamić J, Jamičić D and Crnko J, 1984b. Petrološki prikaz ultramafita iz metamorfnog kompleksa središnjih dijelova Psunja. Rad JAZU 141(20): 93-104.

Pamić J, Lanphere M and McKee E, 1988a. Radiometric Ages of Metamorphic and Associated Igneous Rocks of the Slavonian Mts. in the Southern Part of the Pannonian Basin, Yugoslavia. Acta Geologica 18/2: 13-39.

Pamić J, Lelkes-Felvári Gy and Raffaelli P, 1988b. Andalusite-bearing schists from the southwestern parts of Papuk Mt. in Slavonija (northern Croatia). Geološki vjesnik 41: 145-157.

Pamić J, Lanphere M and Belak M, 1996. Hercynian I-type and S-type granitoids from the Slavonian Mountains (southern Pannonian Basin, northern Croatia). Neues Jahrbuch fur Mineralogie Abhandlungen 171/2: 155-186.

Pamić J, Balen D and Tibljaš D, 2002. Petrology and geochemistry of orthoamphibolites from the Variscan metamorphic sequences of the South Tisia in Croatia - an overview with geodynamic implications. International Journal Earth Science 91: 787-798, DOI 10.1007/s00531-002-0258-y.

Raffaelli P, 1964. Metamorfizam paleozojskih pelitskih škriljaca u području Ravne gore (papučko gorje - Slavonija) (Metamorphism of Paleozoic pelitic schists of Ravna gora (Papuk Mountain - Croatia). Geološki vjesnik 18(1): 61-111 (in Croatian).

Schmid SM, Bernoulli D, Fügenschuh B, Matenco L, Schefer S, Schuster $\mathrm{R}$, Tischler $\mathrm{M}$ and Ustaszewski $\mathrm{K}, 2008$. The AlpineCarpathian-Dinaridic orogenic system: correlation and evolution of tectonic units. Swiss Journal of Geoscience 101: 139-183.

Schmid SM, Bernoulli D, Fügenschuh B, Georgiev N, Kounov A, Matenco L, Oberhänsli R, Pleuger J, Schefer S, Ustaszewski K and van Hinsbergen D, 2016. Map of the Tectonic units of the Alpine collision zone between Eastern Alps and Western Turkey.

Shand S, 1927. Eruptive rocks. Their genesis, composition, classification and their relation to ore-deposits, 1rd edition, Thomas Murby \& Company, London, 488pp.

Sláma J, Košler J, Condon DJ, Crowley JL, Gerdes A, Hanchar JM, Horstwood MSA, Morris GA, Nasdala B, Turbett MN and Whitehouse MJ, 2008. Pleŝovice, a new natural reference material for $\mathrm{U}-\mathrm{Pb}$ and $\mathrm{Hf}$ isotopic analysis. Chemical Geology 249: 1-35.

Slovenec Dr and Bermanec V, 2003. Sistematska mineralogija - mineralogija silikata. Manualia Universitatis studiorum Zagrebiensis, Denona Zagreb, 359pp (in Croatian).

Stacey JS and Kramers JD, 1975. Approximation of terrestrial lead isotope evolution by a two stage model. Earth and Planetary Science Letters 26: 207-221, DOI 10.1016/0012-821X(75)90088-6.

Sylvester PJ and Ghaderi M, 1997. Trace element analysis of scheelite by excimer laser ablation-inductively coupled plasma-mass spectrometry (ELA-ICP-MS) using a synthetic silicate glass standard. Chemical Geology 141: 49-65.

Szederkényi T, 1996. Metamorphic formations and their correlation in the Hungarian part of Tisia Megaunit (Tisia Megaunit Terrane). Acta Mineralogica-Petrographica XXXVII, 143-160.

Tajder M, 1966. Geneza blastoporfirnog epidot-amfibolita na području Omanovca u Psunju (The petrogenesis of blastoporphyritic amphibolite in the region of Omanovac in Psunj). Acta geologica 6, Razred za prirodne znanosti knjiga 36: 5-16 (in Croatian).

Vragović M, 1965. Graniti i gnajsi Papuka (Granites and gneisses of the Papuk Mountain). Unpublished PhD Thesis. University of Zagreb, 222pp (in Croatian). 